\title{
RISO E ENIGMA EM SÓCRATES
}

\author{
ADRIANO MACHADO RIBEIRO* \\ Faculdade de Letras, Filosofia e Ciências Humanas \\ Universidade de São Paulo
}

\begin{abstract}
RESUMO: $O$ artigo busca mostrar como as diversas manifestações de alegria no Eutidemo de Platão contrapõe-se à seriedade exigida por Sócrates para a filosofia. Sendo assim, o riso, o sorriso e a gargalhada pressupõem um saber que humilha um interlocutor tratado como antagonista. A tarefa da filosofia, por sua seriedade investigativa, deve deixá-los de lado. Platão, contudo, não deixa de lançar no diálogo certo sorriso ao leitor. Na Apologia, além disso, a tarefa socrática parece provocar um riso semelhante aos jovens do Eutidemo. Mas por que Platão, enigmaticamente, não o diz claramente?
\end{abstract}

PALAVRAS-CHAVE: riso; filosofia; Apologia; Sócrates; Platão; Eutidemo.

\section{Introdução}

O leitor atento, tendo lido o título, de imediato poderia, manifestando-se, indagar o que dele esperaria mas aí não se encontra: "por que não é o sorriso de Sócrates?" E a razão aparecer-lhe-ia de imediato, pois o certo, poderia ele pensar, seria associar Sócrates à ironia. E esta parece se modelar por um leve sorriso apenas esboçado, parcimoniosamente: manifestação suave e imperceptível de uma clarificação entredentes. Urbana e polida, recordaria o culto leitor, a atitude de Sócrates assim ganha relevo ao ser contrastada com o embaraço aporético do interlocutor dos diálogos de Platão, sobretudo dos denominados socráticos. O leve esgar do sorriso socrático apenas reforçaria o contraste com um interlocutor sempre mais rude e irritado. Não que aqui não possa ocorrer o mesmo: o leitor familiarizado com Sócrates, de imediato sorridente com o título, não pode, por fim,

* Professor do curso de Graduação em Grego do Departamento de Letras Clássicas e Vernáculas daFFLCH/USP. 
agastar-se com a produção cansativa e desajeitada deste autor, que, no esforço por produzir o riso em Sócrates, acaba por aqui reiterar, para além do próprio, também o enfado acadêmico? Ciente dos riscos, resta ao leitor um pedido do autor: complacência e condescendência para chegar ao fim.

O escopo aqui, de qualquer modo, não será negar a razão da pergunta do leitor, ancorada numa interpretação mais ampla cujo efeito é modelar um certo Sócrates a partir de recursos presentes em vários diálogos de Platão. Sem deixar de assinalar o mérito, bem como a dificuldade, de tal tarefa, a resposta que busca neste texto justificar o título circunscreve-se em limites mais determinados, visto se busque traçar no realce de contornos específicos: em primeiro lugar, demarcando, no Eutidemo, as mais diversas e várias descrições do que se circunscreve na manifestação facial de lábios e dentes, sonora ou silenciosamente, numa leitura do texto de Platão tediosamente próxima e, ao mesmo tempo, de amplitude panorâmica para estabelecer a relação entre o rir e o filosofar; em seguida, em contraposição a esses diversos traços do Eutidemo, verificar como, por meio de um sorriso silencioso, a Apologia parece ecoar, ainda que não sonora gargalhada, ao menos um riso amplo e depreciativo de uma audiência que se modela em proximidade com o ع̌prov socrático. Isto implica, de algum modo, a depreciação do interlocutor refutado pelo rir alheio. Mas, porque divinamente sancionado, tal "̌pprov justificar-se-ia, já que talvez modelasse seu riso em brilhante clarividência enigmática, na divindade de Apolo?

\section{$1^{\mathrm{a}}$ parte}

O Eutidemo, desde o início, apresenta como questão possível uma atividade sempre negada pelo Sócrates dos diálogos estritamente socráticos de Platão; ou seja, a partir da possibilidade do ensino, a implicação e conseqüência de tal prática. Indagado por Críton - na conversa entre os dois que serve de prólogo e ponte para a posterior narração - acerca de quem com este conversava no dia anterior, Sócrates responde afirmando serem dois estrangeiros. De imediato, o que como despretensiosamente efetua discursivamente uma proliferação e, como inevitável fosse assim deduzir, Platão faz Críton concluir serem tais interlocutores novos $\sigma o \phi ı \sigma \tau \alpha^{\prime}$. Nesta perspectiva, cabe, de imediato, saber-lhes a sophia, para explicitar um recorte na amplitude de interesses da espécie, o que Sócrates faz ao explicitar

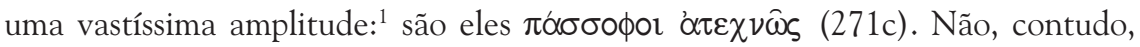

1 Não cabe aqui, conforme os objetivos traçados, se deter neste efeito do elogio pelo seu contrário, por que de algum modo Platão teça a ironia socrática. Longe está, contudo, 
em amplitude desqualificada. Ao contrário, gravitam, como lutadores, em torno dos combates, tornando, em razão do ensino implicado - também os que deles se aproximam a eles semelhantes, desde que recebam salário. ${ }^{2} \mathrm{E}$ assim da luta física com armas tal saber deles se estende ao combate no tribunal e, mediante pagamento, propõe-se ao outro a possibilidade de a eles tornarem-se semelhantes.

É aqui então, juntamente com o combate, o ensino explicitado $\left(\delta 1 \delta \alpha \xi_{\xi} \alpha l\right.$ $\lambda \dot{\varepsilon} \gamma \varepsilon ı v)$; a seguir, a última novidade dos irmãos: o combate em palavras que refuta

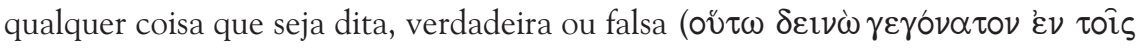

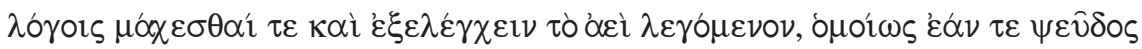

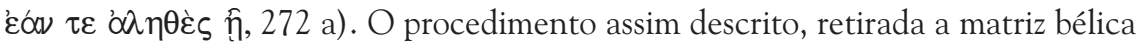
e a não especificidade qualificadora da adjetivação, ${ }^{3}$ refere o verbo com que Platão também particulariza a tarefa socrática, seu eprov específico, desde a Apologia. A molda de Platão assim os efetiva a partir, contudo, de uma especificidade formulada como distante de Sócrates, o combate. Marcada, no entanto, a distância, há a proximidade: o $\dot{\varepsilon} \lambda \dot{\varepsilon} \gamma \chi \varepsilon \imath \nu$, refutar que na Apologia também discrimina a tarefa socrática. O efeito é, no entanto, outra vez o contraste, pois Sócrates afirma a Críton que vai entregar-se a ambos para também ele ser $\delta \varepsilon \imath v o ́ s ~(272 b)$, como se desconhecesse tais atividades.

À observação de Críton de que Sócrates já se encontra muito velho para isso, este responde, curiosamente, salientando que o aprendizado dos irmãos também só ter se iniciado quando já eram ambos velhos. A refutação parece assim, em seus bons ou maus usos, sempre apontar para a maturidade do exercício dos $\lambda$ ó $\gamma 0$. Desse modo, diz ele, a erística, ${ }^{4}$ бoфí $\alpha$ que eles praticam, pode, e talvez só possa ser, apreendida em seus traços mais terríveis por alguém mais velho.

neste caso, de ela se estabelecer pela sinceridade e complexidade que dela amiúde se fala. Tal efeito, como recidiva, se aplica no traço biográfico que estende a profissão dos irmãos em uma espécie de pancrácio que contra tudo combate: da luta corporal passa à jurídica, como misto, e, por fim, àquela que o diálogo consagra, a erística que aqui não deixa de se confundir com a dialética.

2 A insistência no misthós e no fato de serem estrangeiros sempre repercute o crivo mais imediato e efetivo em érgon da separação em que Platão demarca mais precisamente as fronteiras dos sophista das de Sócrates.

3 Pois deinós na Apologia é a qualificação recebida por Sócrates pelos adversários, lá recebendo o contorno pela molda socrática: ele aceita ser chamado de deinós rhétôr, desde que isso implique dizer a verdade.

4 O élenchos tem, pois, explicitada sua antistrophe. 
É neste momento, contudo, que, neste diálogo repleto de menções ao rir, ${ }^{5}$ Platão pela primeira vez o menciona. Sócrates assim teme que com os irmãos ocorra o mesmo que com seu professor de cítara: seus colegas de sala dele riem $(\kappa \alpha \tau \alpha \gamma \varepsilon \lambda \hat{\omega} \sigma \mathrm{r})$ e o nomeiam como professor - mestre - de velhos ( $\gamma \varepsilon \rho \circ \nu \tau o \delta ı \delta \alpha ́ \alpha$ $\sigma \kappa \alpha \lambda \circ \nu, 272 \mathrm{c})$. A primeira menção ao riso assim se apresenta em dupla referência, pois, além de marcar, aos olhos arrogantes desta, o aprendizado como próprio da juventude, implica a desqualificação daquele que se lança à tarefa de ensinar homens mais velhos. Sendo assim, o riso é desqualificador, explícito e partilhado por uma classe, a dos jovens, que, mesmo sem possuírem um saber, demarcam a especificidade do aprendizado deste para si mesmos.

O efeito resultante desta menção é a recusa possível dos irmãos de ensinar Sócrates. O temor, pois, da desqualificação do público-alvo de uma atividade remunerada é efetivada por Sócrates como distância que pode separá-lo do aprender. Para tanto, Platão o faz propor a persuasão de outros homens mais velhos que com ele se disponham a aprender. Críton é assim convidado, pois a ele acompanharão seus filhos (272d). A proposta se modela assim pelo persuadir de Sócrates aos mais velhos, o que parece implicar uma aceitação firmada na conviç̧ão de que pais levarão mais filhos, quantificando por acréscimo o pagamento e, portanto, o salário destes $\sigma o \phi i \sigma \tau \alpha$ í. Os velhos serão, pois, aceitos no ensino como isca para a eventual maior presença de jovens.

Críton, na seqüência, diz aceitar a tarefa, desde que Sócrates exponha a

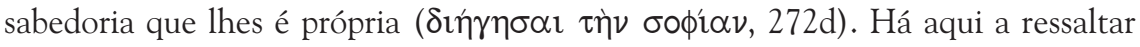
que a ressalva de Críton é modelarmente socrática: é preciso saber qual a ciência e o que com eles se aprenderá. É então que Sócrates inicia a diégesis: o narrar ( $\delta ı \eta \eta \tilde{\sigma} \sigma \alpha \sigma \theta \alpha \imath 272 d)$ do encontro do dia anterior. Sentado só no Liceu, Sócrates

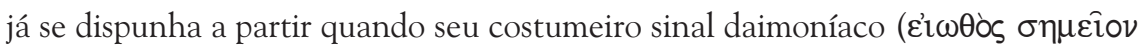

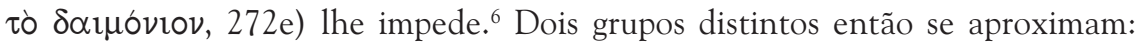
Eutidemo e Dionisodoro com um grupo de jovens alunos ( $\mu \alpha \theta \eta \tau \alpha \hat{\imath})$; Clínias e outro agrupamento, vário de amantes ( $\left.\varepsilon \rho \alpha \sigma \tau \alpha^{\prime}\right)$ ), dentre os quais um se destaca,

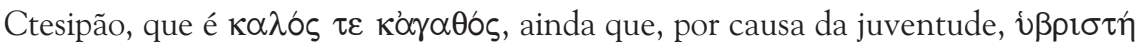
५. Dois professores, pois, de um lado, com seu grupo de alunos, serão, nesta monta-

5 "Ces trois verbes, à savoir, $\gamma \varepsilon \lambda \alpha \alpha \omega, \mu \varepsilon 1 \delta$ ió $\omega, \kappa \alpha \chi \alpha \dot{\alpha} \zeta \omega$ (ainsi que leurs dérivés et leurs composés avec préverbes) sont employés dans des contextes identiques pour signifier des types différents de 'rire' ou des champs d'action du rire (Eire, 2000, 14).

6 Ainda que presente apenas aqui, o sentido divino da tarefa de Sócrates não deixa de ser apontado. 
gem agonística, confrontados com aquele que se destaca num grupo de amantes. Ensino e relações eróticas, em semelhança com o Fedro, aqui se entrelaçam como que em oposição. Todos, contudo, confluem e gravitam em torno de Sócrates, que, imantado, assim se apresenta como referência e, posteriormente, como uma espécie de mediador da já possível contenda. Ele é assim apresentado por Platão neste espaço cênico como eixo de modalidades do ensino e do erotismo. Antes só, ele passa então a ter em torno de si os dois grupos, pois, após Clínias ter se sentado ao lado dele, os dois irmãos deixam de circular em torno para também dele se aproximar.

Após os cumprimentos em que explicita o longo tempo sem ver os dois irmãos, Sócrates os apresenta a Clínias como conhecedores, não de pequenas, mas de grandes coisas ( $\varepsilon \pi \hat{\imath} \sigma \tau \alpha \sigma \theta \circ v)$, tudo que ao combate se relaciona: guerra, táticas e estratégias; bem como no campo dos debates jurídicos.

Ocorre aqui então o segundo riso, pois os irmãos riem (' $\varepsilon \gamma \varepsilon \lambda \alpha \sigma \alpha ́ \alpha \tau \eta \nu, 273 \mathrm{~d})$ de Sócrates, já que eles a aqueles se dedicam como atividades secundárias ( $\pi \dot{\alpha}$ $\rho \varepsilon \rho \gamma \alpha)$. O riso outra vez pressupõe ignorância. No caso, fortuita e casual porque desatualizada, como se Sócrates lhes desconhecesse a importância, visto que ora

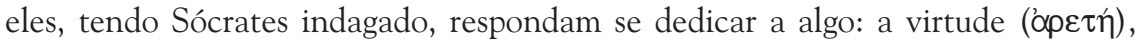

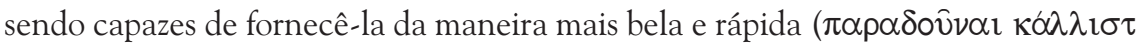

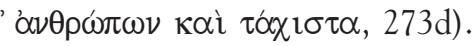

Sócrates explicita a razão do espanto. $\mathrm{Na}$ visita anterior à cidade ( $\varepsilon \pi \varepsilon \delta \eta \mu \eta \sigma \delta \alpha \tau \eta \nu)$ ambos anunciaram que eram terríveis no combate em armas. Platão faz, pois, proliferar a freqüência na cidade, outra condição de um sophistes, assim como a variedade de interesses e conhecimentos, sempre em possível ampliação a partir de uma novidade. Ao estático de um saber específico, contrapõe-se, pelo riso, a variedade de uma molda sempre proliferante e ajustável a novos saberes. Como agora, contudo, Sócrates diz que este novo conhecimento torná-los-ia deuses, ele

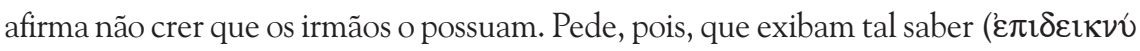
$\nu \alpha \imath \tau \alpha v ́ \tau \eta \nu \tau \eta \dot{v} \sigma o \phi i \alpha \nu, 274 a)$. Novamente adentra aí uma atividade em Platão qualificada como sofística: o exibir-se. Por isso a resposta é imediata. Eles lá estão para exibir e ensinar qualquer um que queira com eles aprender.

Platão narra então, por meio de Sócrates, seu narrador-personagem, este outro prólogo, o da narrativa, modelando assim a disposição cenográfica em que se apresentam as várias disposições das demais personagens. Nesta não estão ausentes interesses eróticos e de grupo de pertença. Dispostos e prontos a aprender ou ensinar em meio a estas inclinações, Sócrates passa a narrar como os irmãos, ao pedido de todos, exibiram o poder da $\sigma o \phi i ́ \alpha ~(274 d)$. 
Sócrates parte do ponto anteriormente estabelecido. Sendo assim, indaga primeiramente aos irmãos se eles ensinam apenas os que já estão dispostos a aprender ou também aos que não foram convencidos. A resposta inclui ambos. Sócrates

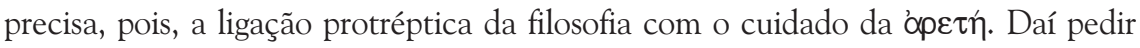

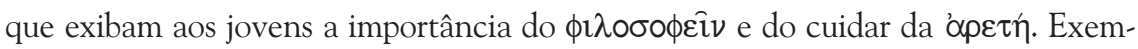
plarmente, deve-se salientar, Platão ali põe o sobrinho de Alcibíades, como para realçar o temor sempre possível de que haja um desvio na conversão e, daí, a corrupção.

O terreno que Sócrates demarca e efetua como próprio dos irmãos aproxima-se assim daquele que os demais diálogos explicitam como particularmente socrático. Não há persuasão outra senão a que reúne o filosofar como atividade à

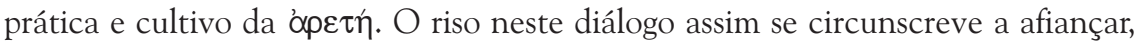
motejando, positiva ou negativamente, na esfera de interesse especificamente socrático. Gravita, pois, em torno de interesses próprios de Sócrates, visto que da amplidão inicial de combates os irmãos passem a restringir sua atuação na esfera de interesse particularmente socrática. Dadas as várias qualificações anteriormente efetuadas sobre eles, evidentemente inicia-se a partir de uma variável sofística, a fim de testá-la no modelo socrático.

Isto mais se evidencia na seqüência, pois a atividade dos irmãos exige do

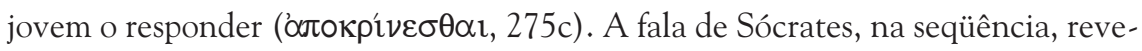
la um curioso aspecto, pois, diz ele, estar o jovem habituado ( $\left.\varepsilon^{\prime \prime} \theta \imath \_\tau \alpha l\right)$ a responder, já que os que ali estão, indo a ele perguntam e dialogam muitas coisas (oí $\delta \varepsilon$

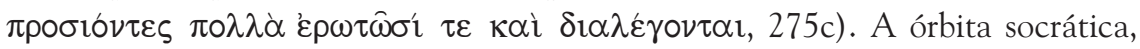
diversamente da Apologia, aqui recebe diferente tratamento. Em primeiro lugar por efetuar estes jovens como interrogantes de alguém que possua talvez um saber. Esta tarefa, como mostra a Apologia, está reservada nos diálogos aporéticos, em geral, ao próprio Sócrates, visto ele afirme só saber que não sabe; em segundo, apresenta o respondente como jovem, sem, portanto, um saber arrogado; por fim, por proliferar, como virtual conseqüência, a tarefa socrática entre jovens que, além de perguntar, dialogam, o que implica participar de uma tarefa que é passível de ser mimetizada. Por isso também, da parte do jovem, o destemor ao responder. Notável, no entanto, é o fato de ele ir se sentar ao lado de Sócrates, o que parece indicativo de uma familiaridade que provém do contato e da proximidade. Platão insidiosamente parece sempre estar a montar este cenário com enredo que aproxima os dois irmãos da atividade que se inclina, via de regra, a ser, em grande parte dos seus diálogos, própria de Sócrates.

Na seqüência, breve interrupção. A narrativa, no que efetiva o término do preâmbulo, que estabelece as personagens no cenário, passa a narrar a questão 
específica do diálogo, ponto central a mostrar em ع̌prov a atividade dos irmãos. Além disso, a retomada do narrar implica repropor o diálogo a partir daquele que

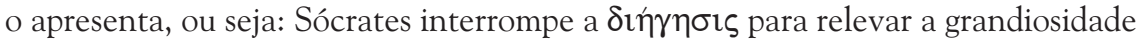

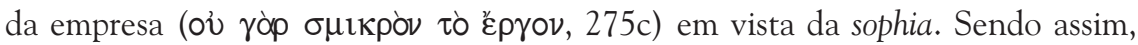

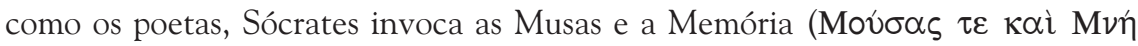
$\mu \eta v)$ para iniciar a narrativa. Há aqui, no uso da interlocução com Querefonte, uma aproximação que se duplica em interlocução que efetiva de algum modo um soslaio ao leitor e dá margem ao entreabrir de um sorriso cúmplice de Platão com quem, ao lê-lo, o compreende. Ironia, se há, ${ }^{7}$ neste caso se presentifica por este sorriso sussurrado, como a possibilitar, na fala retomada de Sócrates com Críton, esta cumplicidade com o leitor que o diálogo efetuará alguma vez mais à frente.

Retomado em seu plano, o diálogo assim começa pela narrativa a mostrar a sophia dos irmãos em ação. E não por acaso a primeira questão de Eutidemo é sobre se quem aprende são os sábios ou os que ignoram. O jovem, porque a coisa indagada fosse grandiosa, enrubescido e embaraçado, lança um olhar para Sócrates, expondo-lhe o temor. Sócrates, no entanto, o incentiva a ter coragem, visto que o benefício e utilidade que daí possam advir lhe sejam favoráveis. A passagem é relevante: mostra que Sócrates tem uma cumplicidade com o jovem e permite, no sentido agônico que está implicado no combate a ser travado pelas palavras, vislumbrar, no olhar dele para Sócrates, este como um treinador. Ou seja, de algum modo ele também se exercita e a outros treina nesta forma de combate.

Ocorre, então, nesta passagem um outro modo de manifestar contentamento: "e nisso Dionisodoro se inclinou um pouco para meu lado e disse com um

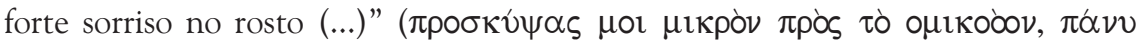

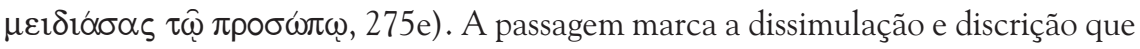
maliciosamente cria uma cumplicidade que sorri de certa ingenuidade do outro. Primeiro, por ser o outro irmão quem fala. Dissimulado, visto se incline e se distancie daquele de quem se fala, com isso revela algum saber outro que ali não se revelará, pois marca exclusividade, por se lançar apenas a Sócrates, com a conseqüente ignorância do interlocutor. Entrevê-se aqui, pois, no outro o que se talvez possa afirmar de Sócrates como personagem de Platão que flerta com o leitor. O sorriso entre os lábios, a dissimulação, o saber que sussurra e ao outro embaraça, pontos afirmados como característicos da ironia socrática, são aqui modelados por

7 Sobre o sentido diverso de ironia comumente atribuído a Sócrates ver Narcy (NARCY, 2000, 289-292). 
Platão como próprios da sua contraparte, o $\sigma o \phi ı \sigma \tau \eta \zeta .{ }^{8}$ Mas não deixa de estar aqui também efetuada por Platão, embora não expressamente, no desnível entre os pedidos de Sócrates aos irmãos e o efetivo não cumprimento da parte destes, já que em geral Sócrates vá dizer o contrário. Na seqüência, Dionisodoro explicita pela fala o que do outro se dissimula: "qualquer coisa respondida será completamente refutada" (' $\varepsilon \varepsilon \lambda \varepsilon \varepsilon \gamma \chi \theta \eta \circ \varepsilon \tau \nu \alpha 1,275 \mathrm{e})$.

Assim, sem que Sócrates o prepare, como Platão adverte, o jovem Clínias responde que são os sábios quem aprende. Como estes, diz Eutidemo, são os professores dos alunos, e são estes quem daqueles aprende: visto que os alunos não saibam e sejam ignorantes conclui que são os ignorantes que aprendem.

O passo seguinte é novamente o do riso sonoro com certos requintes agonísticos de comédia: "tendo assim falado, como se fosse sob o sinal do mestre de coro, ao mesmo tempo balburdiaram e riram ( $\dot{\varepsilon} \gamma \hat{\varepsilon} \lambda \alpha \sigma \alpha \nu)$ os seguidores de Dionisodoro e Eutidemo" (276b). O riso claro e sonoro revela nitidamente o sentido agonístico, visto exiba o diálogo como competição que contrapõe no embate o despreparo do jovem ante as armas vitoriosas de um mestre. Pública, a derisão confirma o temor daquele que, derrotado, sofre do riso a humilhação, já anteriormente antevista no rubor da face.

E a vitória não dista da exibição. Sendo assim, na seqüência, Dionisodoro segue os passos do irmão sem que a vítima, Clínias no caso, possa mesmo recobrar a respiração. A pergunta versa então sobre quais dentre os alunos são os que aprendem. Como Clínias responda que são os alunos sábios e não os ignorantes, Dionosidoro salienta ter sido a resposta anterior ruim.

Os adoradores ( $\varepsilon \rho \alpha \sigma \tau \alpha \hat{\imath})$ dos dois irmãos novamente muito balburdiam e riem, porque comprovassem a $\sigma 0 \phi i ́ \alpha$ de ambos (276d). Os demais, em que Sócrates

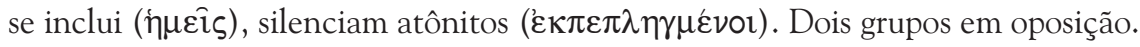
A vitória humilhante de um revela, pois, a ignorância humilhada do outro. A risada sonora, ainda não gargalhada descomposta, revela a superioridade em que $\mathrm{o}$ riso é tornado mais eloqüente pelo silêncio do oponente. Altivo, implica saber. Cúmplices, os adoradores dos irmãos compõem-se como grupo erotizado em que

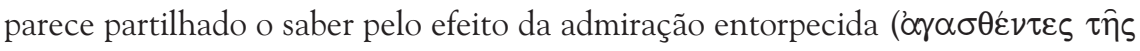
бoфías àvoîv, 276d).

E o procedimento, o que é incessante, reinicia-se. Eutidemo captura o espanto e prossegue interrogando. Novamente marca-se a cumplicidade de Sócrates,

8 Mas não é semelhante o procedimento de Platão na invocação de Sócrates para iniciar a narrativa? 
pois Dionisodoro sussurra a Sócrates que o efeito será o mesmo, pois curiosamente: "nós questionamos todas as questões como estas, inescapáveis" (276e). Assim prossegue a exibição dos irmãos: o saber ora é conhecimento do que se sabe ora o contrário, dependendo da resposta. Uma possibilidade, sendo afirmada pelo jovem, adentra o outro irmão e leva o interlocutor a responder o contrário do que há pouco afirmara.

A aproximação com o ع̌prov do Sócrates descrito na Apologia não deixa aqui de ser patente. Como lá, os irmãos também não deixam de refutar qualquer interlocutor que eles indaguem. Duas características, ao menos, são comuns: o sempre interrogar, e nunca responder; o refutar qualquer que seja a resposta pelo interlocutor. Por isso mesmo, no Eutidemo, na narrativa de Sócrates, este, neste momento, ante outro riso já entrevisto, mas não efetivado, pelas respostas dos irmãos, interrompe o questionamento. Sócrates aproxima o procedimento dos irmãos a um rito iniciático, os mistérios coribânticos. A correção dos nomes, de acordo com Pródico, faz parte deste primeiro momento (277e). Aprender pode, pois, ter dois usos diversos. Os irmãos, para Sócrates, assim brincam ( $\pi \propto 1 \delta 1 \alpha \alpha)$ com sentidos diver-

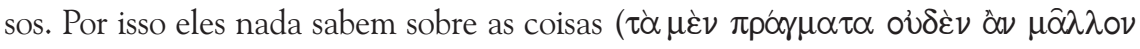

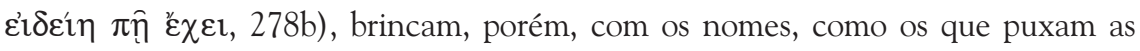
cadeiras dos que estão a ponto de sentar divertem-se e riem ( $\chi \alpha i$ ipovol $\kappa \alpha \grave{\imath} \gamma \varepsilon \lambda \hat{\omega} \sigma \mathrm{l}$ ) dos que caem. Há, pois, a possibilidade de se apreender do trecho que uma coisa é o jogo que se detém no jogo das palavras; outra, uma interrogação que se esforce na investigação dos $\pi \rho \dot{\alpha} \gamma \mu \alpha \tau \alpha$. Mas, antecipando o reverso na Apologia: como não riem os que se alegram com os que caem, sobretudo se em vez de jovens forem homens mais velhos? Se forem afirmantes de deter um saber em vez de apenas estarem dispostos a aprender? De qualquer modo, aqui no Eutidemo Platão modela um Sócrates que parece afastar do riso e do jogo uma investigação outra. Daí Sócrates propor a Clínias uma exibição, por parte dos irmãos, de coisas sérias ( $\sigma \pi \circ v \delta \alpha i ̂ \alpha$ 278c). O brincar se separa da seriedade de uma sabedoria proptréptica. ${ }^{9}$

A exibição deve, segundo Sócrates, por isso mesmo, ser uma exortação

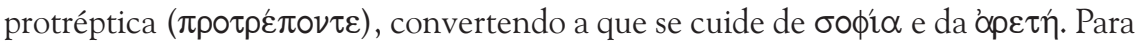
isso, Sócrates apresentará ( $\varepsilon v \delta \varepsilon i$ $\xi o \mu \alpha 1)$ como a compreende e o que deseja ouvir (278d). Alerta, no entanto, que, se parecer fazer isso amadora e ridicularmente

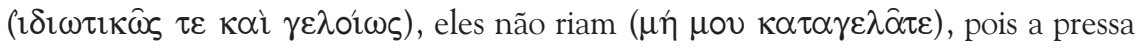
de ouvi-los - no modo pelo qual ele diz que se prontificará, na seqüência, a ouvir -

9 Para uma análise diversa, ver Narcy (NARCY, 2000, 288-9). 
implica a improvisação. Esta, por sua vez, o que novamente se reitera, acarreta que sem riso eles devem ouvir, tanto os irmãos como os discípulos ('ová $\sigma \chi \varepsilon \sigma \theta \circ v$ ov̂v

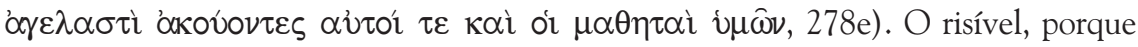
implique o ridículo, parceiro do jogo, contrapõe-se à seriedade que leva à sabedoria

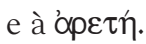

Sócrates propõe, pois, amadora e risivelmente sem manifesto riso, seu modelo. Retoma o procedimento dos irmãos, o de indagar Clínias, agora filho de Axíoco, pois, diversamente dos dois irmãos, trata-se de um concidadão mais jovem. As perguntas também agora precisam um ponto: são um questionamento sobre os valores que lhe devem guiar na vida. Por isso a primeira indagação socrática é se todos querem ser felizes ( $\varepsilon \tilde{\delta} \pi \rho \alpha ́ \tau \tau \varepsilon \imath v)$. A questão é de pronto cercada pelo temor da ameaça há pouco explicitada, dado o riso que a desqualificaria, pois é estupidez

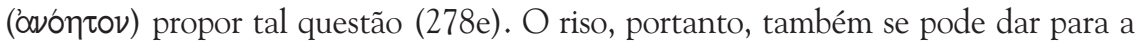
audiência pela desqualificação do que seria, na Apologia, a própria possibilidade de questão humana, a mais importante e precisa que o homem deveria se fazer. O curioso é registrar que assim o riso dela deve se afastar, visto a seriedade implicada. E, o que reforça, segundo Sócrates, ainda mais a ingenuidade e simplicidade, é a pergunta que com a primeira se relaciona: ser feliz ocorre, em geral, se tivermos muitos bens, tendo riquezas; saúde e beleza com relação ao corpo; o bom nascimento e as honras ( $\left.\tau \mu \alpha \alpha^{\prime}\right)$ na cidade; por fim, sendo sábio, justo e corajoso, num crescente de virtudes do que vêm externamente para aqueles que compõem a alma.

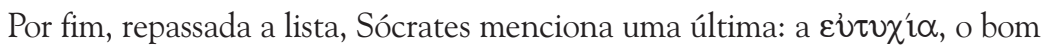
êxito. E novamente é Sócrates quem propõe o riso hipotético, o dos assistentes; com efeito, diz ele, propor novamente o que já fora acordado é risível

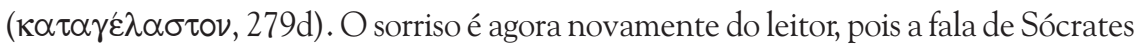
inverte expectativas. O riso é produto da ignorância do que é propriamente socrático. Sabedoria ( $\left.\sigma \circ \phi^{\prime} \alpha\right)$ é, assim, bom êxito. Numa epagoge comprova-se a afirmação: o flautista, o leitor, o condutor do navio têm êxito porque sabem (279e), exemplos que levam à conclusão de que o êxito se obtém quando se tem quem saiba. A бoфí $\alpha$, por toda parte, faz os homens terem êxito (280a).

Sócrates prossegue. Os bens só o serão se utilizados. Não basta possuí-los. $\mathrm{O}$

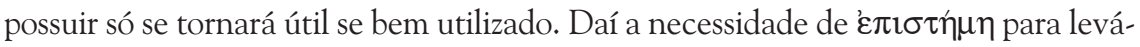
lo a bom termo (281a). Daí a inversão: sem saber, age-se menos, o que acarreta menores erros e, por conseguinte, menor infelicidade. A questão dos bens é, pois, menos deles por si mesmos, e mais da utilização que deles se faz. (281 d-e). A бoфít é, portanto, um bem; a ignorância ( $\alpha \mu \alpha \theta i \alpha)$, um mal. O homem deve aspirar se tornar mais sábio, sendo esta a maior dádiva que um amante pode dar. Como o saber 
é ensinável, e não vem pelo acaso, é a ele que deve se dirigir o homem na busca da

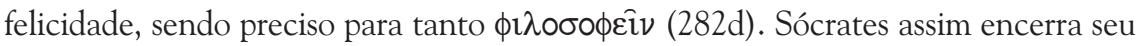
questionamento protréptico: exortando, amadora e longamente, dando a direção

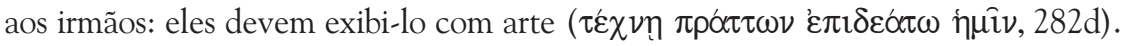

Sócrates, então, interrompe a narrativa a fim de reforçar, explicitando-o a Críton, para além da fala o impacto dela sobre os irmãos. Platão faz assim Sócrates retomar a narração para realçar para Críton o efeito do lógos surpreendente dos irmãos sobre a areté $^{10}$ (283b). E o mais velho, afirma Sócrates retomando a narrativa,

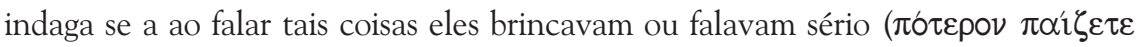

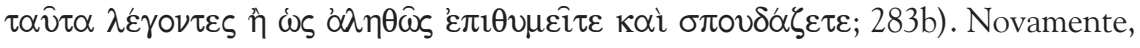
pois, o registro da seriedade em contraponto ao do jogo se apresenta. Agora, em outro registro; com efeito, a argumentação de Dionisodoro, confirmada a seriedade por Sócrates, implica o passo conseqüente: que Clínias passe de ignorante a sábio acarreta querer que ele se torne o que não é, ou seja, que ele morra (283c-d). A conclusão, na chave do sério, leva o amado à morte. Ctesipo, o amante, reage, sem adentrar nas regras deste jogo, indignado. A mudança de registro, de um a outro passo, implica o jogo com as palavras, mas sem que agora ecoe o riso. Ao contrário, implicada a ausência de brincadeira e riso, o embate toma proporções maiores. $\mathrm{O}$ amante assim sai em defesa do amado contra a argumentação, acusando-a de mentira. Sem o riso, e em meio ao agravamento da contenda, intervém Eutidemo e lança a discussão para um tom mais genérico. A mentira, implica o argumento, não existe, pois só se diz apenas exatamente um dos seres quando se diz algo, distinto dos demais (284a). Só há verdade: o que não se diz é que não é. A situação do diálogo mais se agrava quando, ao Ctesipo afirmar que as pessoas de bem falam bem e as más, mal, Eutidemo conclui que as quentes falam o quente, as grandes, o grande. A resposta de Ctesipo é que as frígidas friamente falam, com intervenção imediata de Dionisodoro: Ctesipo o ofende. Este responde que, como amigo, aconselha a que ele

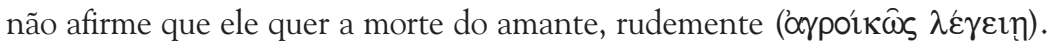

Diante do perigo da mútua agressividade que se contrapõe às normas no diálogo da polidez, Sócrates intercede: vale o risco morrer, desde que seja para se

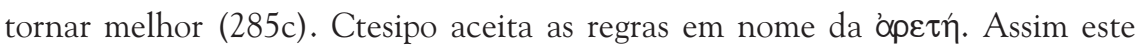

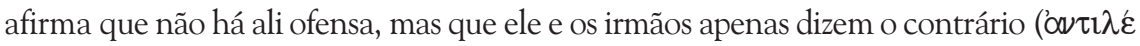
$\gamma \varepsilon ı v, 285 \mathrm{~d})$. Na seqüência, contudo, Dionisodoro afirma não haver contradição: quando

10 O recurso parece se estender de Críton ao leitor: como se suas palavras, para além do interlocutor, atingissem a cumplicidade pelo sorriso de Platão entrevisto pelo leitor do diálogo. 
se fala, de duas uma: ou se fala a verdade ou nada se diz, como, intervindo aqui, Sócrates conclui o raciocínio daquele. Este, porém, objeta: mesmo que não se possa

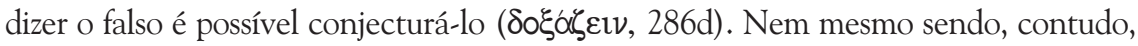
isso possível pela afirmação de Dionisodoro, resta a Sócrates concluir que não há igno-

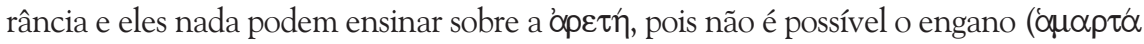
veเv, 287a).

Sem riso dos interlocutores, talvez com um sorriso do leitor, a objeção de Sócrates é descartada, pois, como Cronos, ele se utiliza de algo que há muito fora dito, mas não

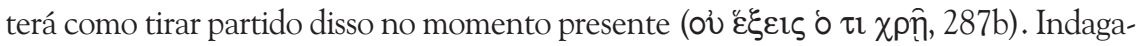
do por Sócrates se tal frase significa ser incapaz de refutar, Dionisodoro recusa a resposta, pois impõe a Sócrates a tarefa de responder. Artifício diversas feitas utilizado por Platão, a passagem de Sócrates para o papel de interrogador é aqui recusada. A condução é dos irmãos.

Cumprida a exigência, Dionisodoro leva as questões à conclusão de que, se só os seres com alma têm sentido, as frases ( $\tau \dot{\alpha} \rho \dot{\eta} \mu \alpha \tau \alpha)$ também deveriam assim sê-lo. Aqui Sócrates denuncia, de passagem, a possibilidade interpretativa operada pelos irmãos que leva, em ambos os casos, à dupla direção das respostas. Ctesipo adentra em apoio de Sócrates, mas de novo rudemente, pois afirma ele que os irmãos dizem tolices ( $\pi \alpha \rho \alpha \lambda \eta \rho \varepsilon i v, 288 b)$. Sócrates outra vez intervém para o exemplar modelo de interro-

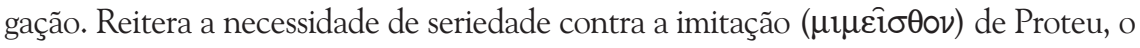

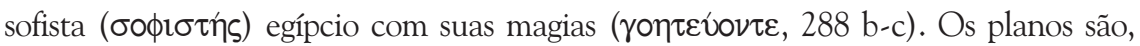
pois, contrários: ao jogo, à magia contrapõe-se a seriedade da filosofia como aquisição

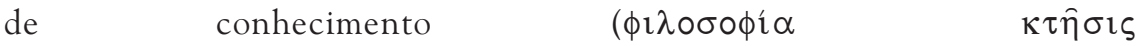

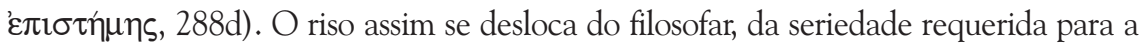
obtenção da felicidade. Ele implora, então, que, ao retomar a discussão com Ctesipo, tal modelo de seriedade exorte os irmãos a praticá-lo também.

Sócrates assim opõe modelarmente os planos. Apresenta, no diálogo com Ctesipo, a maneira como se deve apresentar a interrogação. Diversamente da prática refutativa da Apologia, o modelo é positivo, pois, além de afirmar que o conhecimento requerido deve saber produzir e utilizar o que lhe é próprio, em que várias téchnai são apresentadas e descartadas por não possuírem ambas as exigências; encaminha-a como dialética, superior aos limites específicos das matemáticas. (290b-c). Resta a busca deste conhecimento. $\mathrm{O}$ caminho apontado, o da política como produção e utilização, resta, no entanto, como via a ser trilhada, ainda que não definida. ${ }^{11}$

11 A passagem é cheia de dificuldades. A menção à política, à caça como próxima à téchne do general, bem como a dialética aqui mencionada apontam para especificidades e meandros que aqui não podem ser tratados. Interessa, é claro, apontar um interlocutor 


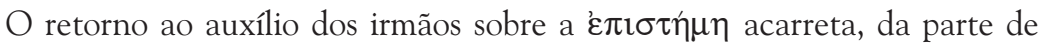
Eutidemo, mostrar ou que já sabe ou que é possível aprender. O problema do Mênon implica, aqui, a resposta ao problema na mais rápida imediatez: Sócrates diz assim preferir já saber. E se, a partir das questões, ele afirma saber não saber algo, por conseguinte, ele será quem sabe e não sabe. Indagado por Sócrates se admite saber algumas e não outras, Dionisodoro adentra e afirma tudo saber. Para Sócrates isso implica saber quantos grãos de areia há na praia. E, para confirmá-lo, Ctesipo, retomando o questionamento, pergunta se ele ao certo sabe quantos dentes têm na boca. A resposta é a reafirmação apenas da afirmativa. A inversão é, diz Sócrates, retomando a narrativa, sentida pelo interlocutor, pois é recusada a resposta por supor que deles escarnecem ( $\sigma \kappa \omega \dot{\pi} \tau \varepsilon \sigma \theta \alpha \mathrm{l}, 294 \mathrm{~d})$. A inversão, pois, do jogo não é aceita pelos irmãos. $\mathrm{O}$ possível riso, produto do escarnecer, é pressentido como enfraquecimento em que, sob o comando deles, a regra é a competição que humilha e derrota um oponente que se vê quedo pelo movimento das palavras adversárias. Mais uma vez, Platão articula o contraste entre o diálogo sério empreendido e requerido por Sócrates do jogo de regras de combate produzido pelas falas dos irmãos. Curiosamente, além disso, Platão parece postergar ao máximo o riso dos demais a partir da fala dos irmãos. Este, embora pressentido, é retardado.

A situação de contraste de procedimentos entre o sério e o jogo é ainda mais marcada à frente, quando Sócrates, depois de não acreditar que eles sempre tudo saibam, diz que gostaria de ser convencido do contrário, pois afirma ter prazer em ser

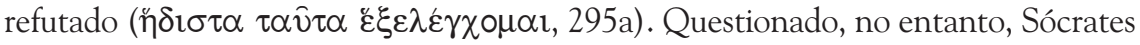
interrompe as questões a fim de aclarar o que lhe perguntam. A inversão possível dos papéis de novo se apresenta. A recusa agora é de Sócrates em entrar no jogo, pois, comenta ele narrando, clarificar as frases objetivava impossibilitar a duplicidade de sentidos dada pelos irmãos (295d). Na seqüência, no entanto, ele cede aos irmãos, pois afirma a Críton que seu escopo principal era aprender algo. Aqui, porém, outra vez se ouve como um sussurro e se vê uma espiadela de Platão que assim se inclina para o leitor. Tal jogo permite a Platão mais uma vez como que sorrir, marcando, deste modo, os limites de ação dos interlocutores, pois tudo é apresentado por Platão a partir apenas do comportamento narrado de Sócrates.

O problema do conhecer prossegue sendo a questão. Indagado se conhece, Sócrates modaliza, explicitando o meio pelo qual, quando, se, e demais modalida-

que, juntamente com Sócrates, encaminha o diálogo para o conhecimento. Sobretudo, ser esta uma atividade séria, distante do riso. 
des que Eutidemo insiste em negar. Afirmado que ele tudo conhece, por não ser possível haver quem conhece e não conhece, Sócrates indaga: sabe ele serem os bons injustos? Na possibilidade de Dionisodoro de outra vez apresentá-lo como conhecendo e não, sofre a repreensão do irmão Eutidemo, pois tal assumpção de Eutidemo implicaria ser quem sabe e não sabe. O rubor, visto antes no jovem Clínias, agora surge no experiente Dionisodoro (297a). Presos nas próprias armadilhas, Platão ora sugere uma disputa entre os próprios irmãos. Sendo assim, Dionisodoro toma a fala, para retomar a exibição de agilidade. Platão faz Sócrates explicitá-lo: as perguntas de Dionisodoro, incessantes, não permitiriam o ensino do irmão ( $\phi \theta \delta ́ v \omega v, 297 d)$. É neste enredo de ininterruptas perguntas que Ctesipo adentra. Levado a afirmar pelas perguntas se é possível ser pai e não ser, de um e de outro, nesta barafunda afirma-se tanto um ser pedra como outro pai de todos, homens e animais, de modo que Eutidemo declara ser pai. Além disso, por ter um cão e dele ser filho Eutidemo conclui ser ele o pai de Ctesipo. ${ }^{12}$ Nisso intervém Dionisodoro e pergunta se Ctesipo bate no seu cão. E outra vez o riso aparece, pois Ctesipo rindo ( $\gamma \varepsilon \lambda \alpha ́ \alpha \sigma \alpha \varsigma, 298 \mathrm{e})$ diz que no cão bate por falta de oportunidade em bater no próprio Dionisodoro. O riso surge agora de modo diverso. Diferentemente do produzido pela humilhação da derrota, este é gerado pela irritação do interlocutor com os argumentos dos irmãos; com a saturação de uma fala que não se esgota, e, de alguma maneira, ainda sob o prisma da competição, se mostra ao interlocutor como vencida.

A constatação da derrota torna-se mais evidente na seqüência. Levando o questionamento para a utilidade das armas, dizendo necessitar em combate de poucas, Eutidemo emudece diante da exemplificação contrária de Ctesipo (249a). Mas não Dionisodoro. Ctesipo, contudo, desprezando a fala deste irmão, aponta o silêncio do outro, que fala sem nada dizer (300a). Recaindo as questões sobre falar calando e calar falando, ${ }^{13}$ Eutidemo procura enredar Ctesipo. Este, aceitando o jogo, e em busca da vitória para impressionar seu amado (300c), indaga, seguindo a linha já traçada pelos irmãos, a da ambigüidade. Eutidemo, por ter explicitado não reconhecer a contradição, assume que se cala sobre o que fala e que, por sua

12 Os comentários aqui, como em outros pontos anteriormente mencionados, vão diretamente à conclusão do argumento, sem se preocupar, dado o fato de nos interessar, neste levantamento geral, em razão dos movimentos cênicos e de enredo do diálogo com relação ao riso a partir das suas manifestações apresentadas.

13 Utilizando-se de uma possível ambigüidade que daí extrai falar das coisas silenciosas e calar das coisas que falam, ver Canto (PLATON, 1989, 224). 
vez, todas estas falam, sem que isso lhe traga problemas. Ctesipo insiste na questão: todas falam ou se calam? Dionisodoro, no entanto, novamente adentra e assume a concomitância da ambigüidade: "nenhuma nem outra e as duas ao mesmo tempo" (300c).

A reação de Ctesipo é contundente e explícita gargalhada (ó K $\tau \eta \dot{\sigma} \sigma \pi \pi \circ \varsigma$,

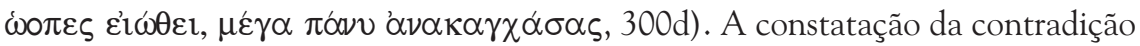
é explicitada por Ctesipo, ao falar a seguir com Eutidemo, como aniquilação e derrota. $\mathrm{O}$ alarido sonoro do riso, a gargalhada, é assim claramente exposta na narrativa de Sócrates a Críton como um hábito a compor um ๆ̄日os. Além disso, diversamente do riso anterior da assistência, ela é produzida pelo próprio interlocutor como humilhação e derrocada do oponente. Sonora, ela não precisa se manifestar em muitos para ressoar. $\mathrm{O}$ jogo assumido por Ctesipo, pontuado pelo

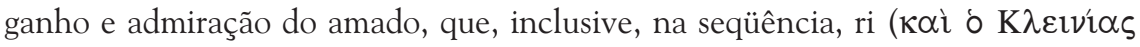

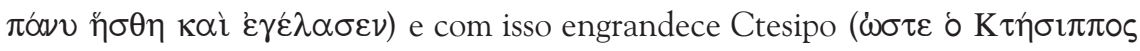

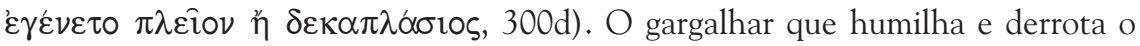
interlocutor ecoa um riso de quem captura, com seu sucesso, o amado, que, por sua vez, multiplica a força do outro por este se saber em meio a alheios olhares. Platão articula, pois, a gargalhada como resultado deste jogo de combates cuja vitória apresenta a obtenção da vantagem de um outro como prêmio.

A intervenção de Sócrates na seqüência, mediada por comentário que explicita a narrativa e apresenta sua discordância para com Ctesipo, pois, invertendo expectativas do que se poderia esperar que ele dissesse, novamente torna claro que coisas sérias e belas estavam sendo apresentadas: pergunta, assim, o por-

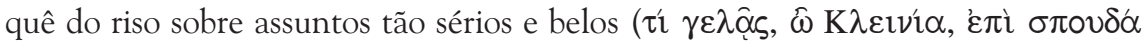

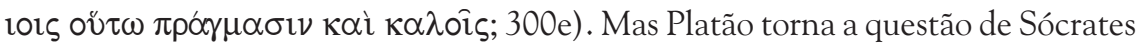
outro mote para o retorno do questionamento de Dionisodoro. O riso se lança, pois, ao leitor ante o reiterado descompasso entre a exigência de Sócrates e os comportamentos indecorosos dos demais interlocutores; com efeito, o fito de Ctesipo é brilhar pelo riso do amante; o dos irmãos, pelos incessantes jogos de sentido. Em comum, os jogos buscam derrotar o interlocutor. Deste modo, Sócrates afirma a Críton o inadequado de sua intervenção, visto esta desencadeie uma série de questões sobre se o belo é belo ou outro do que ele mesmo. Interessa nesta outra delonga de Dionisodoro sobrelevar o comentário de Sócrates, já que se passe a discutir se o mesmo é mesmo e o outro é outro: assim como aos artesãos convém produzir algo específico, no caso dos irmãos produzir o dialogar convém de modo

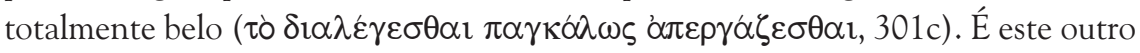
mote para a exibição dos irmãos. E o procedimento segue: a cada intervenção de 
Sócrates discute-se a afirmação e possíveis implicações sempre inusitadas. Sendo assim, acaba, segundo os argumentos dos irmãos, por se cortar o cortado, forjar-se o forjado; além disso, se se tem um animal e um deus, é conseqüente que se possa a ambos vender e dispor. Platão reitera, pela narrativa de Sócrates, ser a exibição incessante, sempre pronta a partir de qualquer ponto mencionado. Não há, nesta tarefa, fim. ${ }^{14}$

Finalmente, após a confirmação de Sócrates para Críton de que tais argumentos de Eutidemo eram assombrosos, Ctesipo grita louvando-lhe a força des-

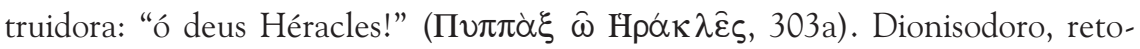
mando a palavra, indaga se a interjeição ou o deus é o sujeito. Ctesipo, retomando a qualificação anteriormente atribuída aos sofistas (271c), afirma-lhes imbatíveis, jogando a toalha ante a perseverança de uma máquina argumentativa que nunca cessa, mas sempre retorna a partir da última coisa que se tenha dito.

Sócrates, então, volta a narrar a Críton. No grande riso ao término da exibição, alcançado o termo final da batalha, Sócrates afirma que, morrendo de rir, de

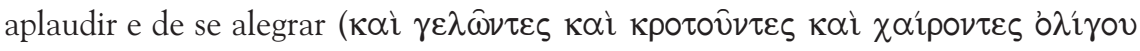

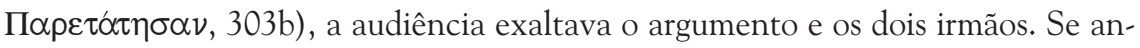
tes (276b), narra Sócrates (303b), apenas os amantes de Eutidemo balburdiavam e riam, em manifesta contraposição agonística, agora todos manifestaram contenta-

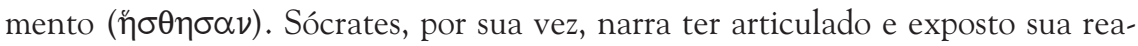
ção, em claro contraponto à balbúrdia. Não há, além disso, em sua narração qualquer manifestação de alegria. Seriamente, ao menos no jogo dos vencedores, cons-

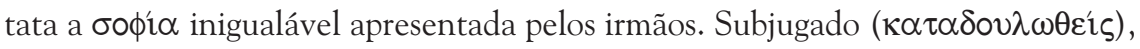

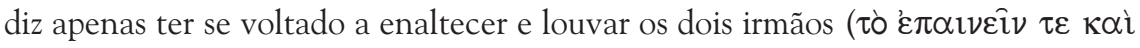

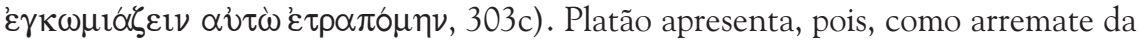
exibição sofística seu efeito esperado, o elogio, visto um como implicação do outro. O curioso é a assumpção deste por Sócrates. Jogando seu jogo, a narração da seriedade requerida para encontrar a felicidade, o resultado da exibição dos irmãos protrepticamente volta Sócrates justamente ao elogio dos dois. Platão mais uma vez parece deixar entrever na fala de Sócrates outro sorriso que se inclina a seu leitor. Pelo avesso, pois, a alegria se diz. A seriedade requerida para a prática do

14 O érgon socrático da refutação, tal como se apresenta nos diálogos denominados aporéticos, curiosamente é infindável produção de dificuldades, ainda que, diversamente do argumento dos irmãos, em geral versem em linhas gerais sobre uma específica questão. Não, contudo, sem meandro. 
filosofar entretece no elogio ao sofista um sorriso enigmaticamente proposto, visto que, se não diz, é como se lançasse sinais.

O elogio de Sócrates insiste na brevidade em obter algo tão difícil. Isso, vale lembrar, fora a propaganda anunciada pelos irmãos: a rapidez na obtenção do que por eles é ensinado (273d). O elogio de Sócrates, contudo, curiosamente se detém na implicação de que se nada é outro, conseqüentemente se cosem não apenas as bocas dos outros, mas, inclusive, a deles mesmos. Justamente por isso, ao

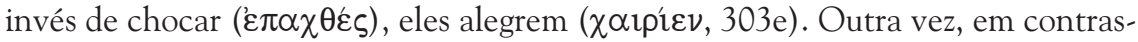
te com a seriedade requerida por Sócrates, elogia-se o alegrar-se do jogo. Platão move as peças, e parece com isso não deixar de novamente entrever um sorriso. Além disso, ponto principal, visto disponham de arte ( $\tau \varepsilon \chi \nu 1 \kappa \omega \hat{\varsigma} \varsigma)$, Sócrates elogialhes que qualquer homem a possa em pouco tempo aprender (303e). A prova é o fato de Ctesipo poder rapidamente imitá-los $(\mu 1 \mu \varepsilon i \hat{\sigma} \sigma \alpha \mathrm{l})$. A passagem não deixa de ser importante. Sócrates já denunciara anteriormente (288b) o perigo da imitação, citando Proteu, o sofista egípcio. O Eutidemo monta assim uma estratégia em

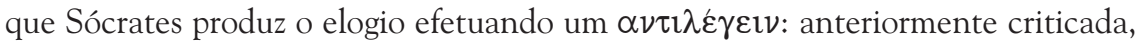
agora a imitação é elogiada. Como, então, não sorrir? Ainda mais pelo fato de Ctesipo ter passado de oponente enfurecido, fora das regras do jogo (283c), a imitador, dado o efeito produzido em seu amado lhe ter sido favorável. O efeito da imitação, contudo, sinaliza para Sócrates uma advertência aos irmãos: é preciso manter tal ensino nos limites do $\delta \_\alpha \lambda \varepsilon \gamma \varepsilon \sigma \theta \alpha \imath$ entre eles mesmos, pois falar assim diante de muitos pode acarretar que estes não lhe rendam reconhecimento, dado o rápido aprendizado que se produz em possível escala de um saber que tudo sabe. Se não entre si, adverte Sócrates, o dialogar deve apenas ter um terceiro que lhes pague um salário (304a). Assim sendo, Sócrates se oferece como aluno, sendo Clínias o próximo, com o que encerra seu elogio e produz Platão um sorriso no leitor.

Finda a narrativa, Sócrates retoma o diálogo com Críton. Platão o faz ora confirmar a Críton que eles podem ensinar qualquer um, não importa a idade, desde que lhes paguem (304c). ${ }^{15}$ Críton, contudo, não parece satisfeito, e diz ser, como Sócrates, alguém que prefere ser refutado ( $\varepsilon \xi \varepsilon \lambda \varepsilon \gamma \chi \propto \mu \varepsilon v \omega \nu)$ a refutar

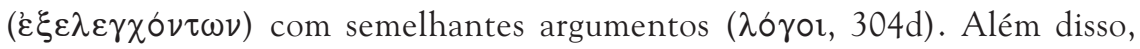

15 Não deixa de ser relevante que na Apologia o fato de não receber salário, bem como o fato de ser um cidadão ateniense, sejam as principais razões apresentadas por Sócrates contra as denominadas antigas acusações, aquelas presentes na comédia de Aristófanes. 
passível de ser ridículo ( $\gamma \varepsilon \lambda$ oîov) por querer aconselhar Sócrates, ele também passa a uma narrativa. Encontrando-se com um sábio, um dos terríveis $(\delta \varepsilon \imath \hat{v} \omega \square v)$ no que concerne aos tribunais, ele diz ter este lhe advertido que, após ouvir-lhes, chegou à conclusão de que eles apenas tagarelam com zelo indigno sobre questões também indignas (304e). A passagem não deixa de ser interessante. Primeiro por levantar uma objeção desta outra personagem, não nomeada, e que explicite, ao contrário de Sócrates, uma objeção contra a prática dos irmãos. Ainda mais por Platão mencionar a possibilidade, apresentada por Críton, de provocar o riso ao aconselhar Sócrates. Sugere, pois, uma indignidade que contrapõe os dois em relação ao saber. Sócrates, dado se aproxime o diálogo do fim, sobreleva-se em debate argumentativo, visto vá contrapor a personagem ora mencionada com argumentos do próprio Sócrates.

A narrativa de Críton, na seqüência, afirma que ele disse a tal interlocutor que a filosofia, ao menos, é coisa graciosa ( $\chi \alpha \rho i ́ \varepsilon v)$. A crítica deste, contudo, afirma que aos irmãos não importa o que digam, usando a primeira palavra que lhes aparece (305a). O problema, afirma ele, é a própria coisa $(\pi \rho o ́ \gamma \mu \alpha)$ e os ho-

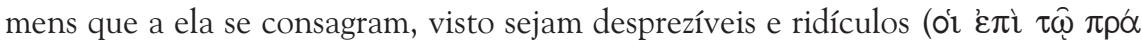

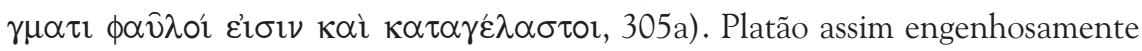
propõe, na última parte do diálogo, o ridículo como crítica à própria filosofia. Se ao longo do diálogo, ela é apresentada, enquanto atividade, como contraponto ao jogo e ao riso sofístico, não fica clara a distinção prática do $\delta \imath \alpha \lambda \varepsilon \varepsilon_{\varepsilon} \sigma \theta \alpha \mathbf{l}$ dos irmãos com relação à mesma prática exercida por Sócrates. Sendo assim, ela vai agora ser focada com relação a seus praticantes. Por isso, última onda, é preciso defendê-la da velha crítica que ri dos que a ela se dedicam. Platão, já de antemão, dá o tom da resposta de Sócrates pela narrativa de Críton, visto este tenha respondido que é preciso distinguir a coisa ( $\tau$ ò $\pi \rho \hat{\gamma} \gamma \mu \alpha)$ dos seus praticantes. Além disso, Críton reforça a fala de Sócrates: o problema é apresentá-la diante de muita gente. $^{16}$

A seqüência do diálogo visa a precisar a espécie a que pertence o autor da

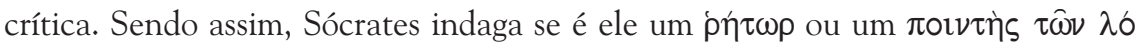
$\gamma \omega \nu$ que contra os primeiro digladia. Sendo da segunda espécie, ele se encontra, segundo Sócrates, na fronteira entre a política e a filosofia. O problema, segundo

16 É tal ponto também uma crítica ao Sócrates da Apologia? Com efeito, lá, como se verá, há um ponto nebuloso em relação à seriedade aqui requerida por Sócrates para a prática da filosofia. 


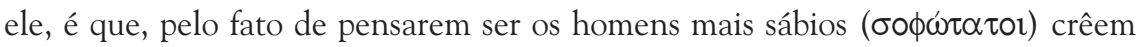
que também pelos outros seriam estimados se não fossem os homens que se dedicam à filosofia a lhes criar obstáculos para aceder a tal reconhecimento (305d). Pensam, pois, que, ao desqualificar a filosofia, serão reconhecidos. Quando são apanhados argumentativamente, em encontros particulares, culpam Eutidemo e os que em torno dele se encontram. Pensam, além disso, ser bom ter moderadamente algo da filosofia, algo da política. O problema, diz Sócrates, é que se ambas são boas coisas retirar um pouco de cada implica ser inferior a ambas. De qualquer modo, deve-se estimar, diz Sócrates, todo homem que se dedica ao pensamento e corajosamente a tal pesquisa se aplica (306d). O ridículo pelo qual acusam a filosofia tem assim seu reverso: a causa é justamente ao fato de serem apanhados na discussão. No fim das contas, não se poderia dizer que chamam a filosofia de ridícula porque é ela que, por meio dos homens que a praticam, torna-os motivo de riso?

Críton então indaga pelo mote, para ele, do diálogo (272d): como deve ele cuidar dos filhos, visto os tenha negligenciado, ainda que por eles tenha feito um bom casamento e obtido boa condição financeira (306e)? O problema, afirma Críton, é que os que se dedicam a educar pareçam muito extravagantes ( $\pi$ ónv

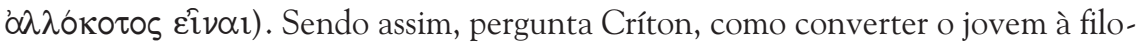

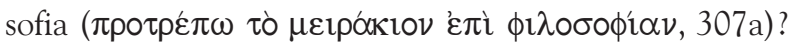

Sócrates afirma, então, que em toda atividade há muitos homens ruins ( $\phi \alpha \hat{v} \lambda \circ \mathrm{l})$ e indignos enquanto poucos são sérios ( $\sigma \pi \circ v \delta \alpha \hat{\imath} \mathrm{)})$ e dignos. As $\tau \dot{\varepsilon}$ $\chi v \propto \imath$ separam-se assim daqueles que as praticam. Por isso, como não se deve fugir das demais, o mesmo vale para a filosofia. Deve-se, pois, conclui Sócrates, consagrar a própria filosofia, deixando de lado os que a praticam (307b). É o valor dela mesma o que deve avaliar se Críton e seus filhos devem a ela se dedicar.

O final do diálogo encaminha à discussão sobre o valor intrínseco da filosofia. Há, no entanto, pela valoração dos homens sérios, uma inclinação sussurrada a efetuar a filosofia como algo também sério. Esta, inclusive, é a exigência de Sócrates ao longo de todo o diálogo. Com isso, o jogo parece ser afastado. Com ele, também, as diversas manifestações de contentamento: sorriso, riso e gargalhada afastam-se da seriedade apropriadamente filosófica porque o escarnecer do outro implica-lhe humilhação, desdém. Como se o reconhecimento da ignorância efetivase uma arrogância de quem se crê saber. Além do desdém, cabe também o riso como eco vitorioso de um embate argumentativo. Neste caso, a filosofia produziria alegres vencedores ao invés de sérios investigadores. A prática, pois, do $\delta 1 \alpha \lambda \varepsilon$ $\gamma \varepsilon \sigma \theta \alpha$ acarreta a reprodução desta prática que, indevidamente utilizada, humi- 
lha, ri e gargalha. Ctesipo comprova o perigo. No entanto, a objeção final trazida por Críton de seu interlocutor anônimo também deve ser afastada. Séria, a filosofia pode e certamente deve ser exercida. Afinal, a virtude e a felicidade, escopo final de todo homem, por ela são alcançadas.

\section{$2^{\mathrm{a}}$ parte}

O riso na Apologia de Platão não se mostra, ao menos claramente, relacionado com a atividade de Sócrates. Como no Eutidemo, o filosofar se apresenta como atividade séria, de homens sérios. A Apologia de Platão assim efetua Sócrates como possuídor de um saber. Este, contudo, nela se expõe como enigma que circunscreve seu uso e aplicação; com efeito, embora Sócrates se diga бoфós, ele restringe seu saber à esfera humana ( $\left(\alpha \omega \theta \omega \pi^{i} i \nu \eta \sigma o \phi^{\prime} \alpha\right)$. A justificativa, contudo, deste saber não é do próprio Sócrates, pois afirma-se como tendo origem divina: a fala pelo qual o enigma se pronuncia é fala do deus (Ap.20e). Sendo assim, o ع̌prov socrático é efetivado como atividade humana cuja razão de ser se encontra no pronunciamento divino. Sua $\sigma o \phi i ́ \alpha$, sendo-lhe própria e única, o separa assim de todos os demais.

A justificativa de seu saber é ancorada em testemunhos. A fala de Sócrates se apropria destes testemunhos para firmar diferenças. Em última instância, é o oráculo quem o diz. Mas por meio da voz humana de Querefonte, amigo de Sócrates. O relato que precisa a especificidade da бopí $\alpha$ de Sócrates é decorrente daquele, que lançara a pergunta à Pítia se havia alguém mais sábio do que Sócrates. Foi dele o testemunho de que o oráculo afirma a negativa.

O бoфós assim se delimita em relação à divindade. Subrepticiamente isso implica a diferenciação um conhecimento sobre-humano que o texto aponta como próprio do sofista. O divino, que não mente, precisa, no entanto, passar pelo crivo da interrogação pelo qual o $\lambda$ ó ${ }^{\circ}$, interpretando-o, se legitima . Inicia-se então a atividade propriamente socrática que é causa na Apologia da acusação contra Sócrates.

O primeiro passo de Sócrates (21b-e) para legitimar o oráculo é com ele exercitar o mesmo pelo que se estende posteriormente a própria atividade socrática,

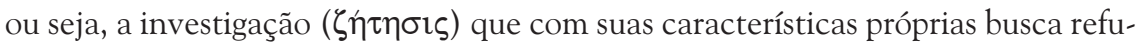

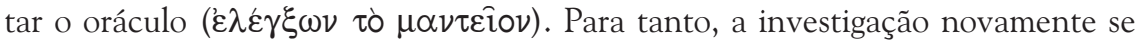
centra na tarefa precípua do texto: circunscrever o бoфós. Como se trata de testar

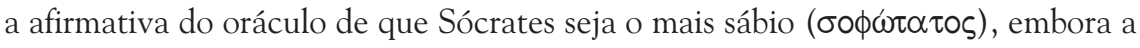
seu ver ele nada saiba, a atividade empreendida passa a ser a de comparativamente 


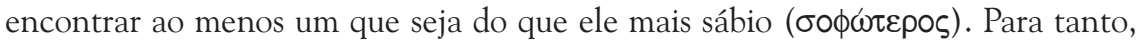
passa a interrogar alguns dos que são reputados como sábios.

Assim um algo semelhante reúne as pessoas inquiridas por Sócrates: o fato de julgarem-se os mais sábios dentre os homens quando não o eram. Apresentado três espécies diversas de homens que comprovam a mensagem oracular, Sócrates refuta políticos, poetas e artesãos. Com isso ele novamente demarca a especificidade do que se constrói como saber humano em sua limitação: o reconhecer sua especificidade, ou seja, o não saber que, no entanto, refuta todo aquele que crê saber algo.

Chega-se assim (Ap., 22e) à confirmação do oráculo. A partir dela Platão pode afirmar a causa pela qual ele é chamado de ooфós : a partir desta pesquisa surgiram-lhe muitas acusações e o nome passou a lhe ser dado. Por crer que Sócrates saiba aquilo que refuta nos demais, os que presenciam os encontros confundem os planos. Não à toa o interlocutor anônimo de Críton no Eutidemo diz algo semelhante. No entanto, planos distintos de saber são, neste caso, opostos. Ao contrário, na Apologia a interpretação do oráculo pela qual Sócrates tem sua missão denominada divina é certa e inequívoca constatação: apenas o deus é бoфós, o ser humano tem pouco, ou mesmo nenhum valor. Neste sentido, o discurso confirma o oráculo, pois Platão apresenta Sócrates como modelo que piedosamente reconhece seus limites. Aqui, na inversão do que é esperado, o бoфós se define às avessas: é o reconhecimento do não saber o que o delimita, como, segundo Sócrates, parece indicar o deus (Ap.23b). Saber do não saber ante o divino; tarefa do deus a investigar primeiro o deus, depois os outros, a tarefa socrática ao fazer-se especifica seu sentido. Ainda que se apresente a reversão de $\lambda \sigma^{\prime} \gamma o$, a $\sigma o \phi i ́ \alpha$ de Sócrates se distingue pela delimitação humana que a especifica. Afirma-se assim como diversa do sofista, visto esta seja qualificada como sobre-humana. No entanto, ao menos na Apologia, formula-se por procedimento semelhante ao do Eutidemo, distinguido-se, pois, pela circunscrição que, visto delimitada, lhe impede o ensino, formulando este como reservado às pesquisas de um Anaxágoras e sobretudo aos sofistas.

Negativa, a sabedoria humana de Sócrates passa a ser, com a confirmação do oráculo, delimitadora. Cabe a ela a refutação de quem se arroga o saber, sem que isso implique outro que o substitua. A afirmação do oráculo, e sua posterior interpretação, passa assim a ser norteadora do ع̌pyov de Sócrates. Este diferenciase, pois, ancorado na confirmação do oráculo. Implica assim tarefa divina. Destaca-se em sua generalidade, visto investigue cidadãos e estrangeiros, com o empenho negativo, pois é mostrar, segundo o deus, que não é sábio quem o afirma. Neste sentido, não implica vantagens: sem tempo para si e para os afazeres da 
cidade, a pobreza, outra marca distintiva em relação aos sofistas, é conseqüência de tal tarefa.

É, pois, o đ̄⿴os de Sócrates elemento diferenciador. Visto Platão o apresente como destituído de saber - pelo que os procedimentos implicados no $\check{\varepsilon} \lambda \varepsilon \gamma \chi \circ \varsigma$ funcionem sempre de modo negativo, exceção feita ao oráculo - a afirmativa que o distingue se mostra positivamente, o que o oráculo corrobora, na constância de um $\lceil\theta 0 \varsigma$ demarcado por procedimentos pelos quais os $\lambda$ ó $\gamma$ or sempre referem os हैpro.

Sócrates é assim apresentado por Platão como diverso da figura do бoфós justamente por se afirmar em consonância com as razões que, invertendo expectativas, transforma $\lambda$ ó $\gamma o$. Tudo, porém, sob sanção divina. $O$ deus dá o aval para um $\hat{\eta} \theta$ os duplamente qualificado: divino e por isso diferenciado; discursivamente pelo que se enseja para além dele porque anterior, simultâneo e posterior a sua fala.

Ter o saber do não saber não permite a Sócrates, deste modo, o ensino. Se

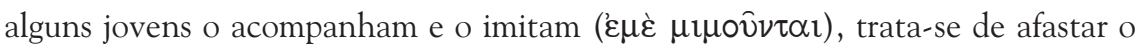
ensino e o recebimento de pagamento. Explica-se pelo tempo livre de que dispóem ( $\sigma \chi 0 \lambda \eta ́)$ o fato de estes jovens serem ricos e por si mesmos acompanhá-lo. Disso resulta que, ao examinar os que se julgam sábios, uma conseqüência se dê: tais homens irritam-se com Sócrates. Esta, diz Sócrates, é uma das principais causas da acusação. É patente aqui a semelhança com o Eutidemo. Neste, no entanto, o imitar é ensino, visto o dialogar se explicite como $\tau \dot{\varepsilon} \chi \nu \eta$. Mas, exceção feita ao pagamento e ao afirmado caráter divino da atividade socrática, pouco se pode distingui-los.

A atividade dos jovens, mimetizando Sócrates, é o elo que na Apologia une antigas a novas acusações. A irritação daqueles que foram examinados pelos jovens é de afirmar que um certo Sócrates é deplorável e corrompe a juventude. Com isso, sem a nomear, Platão põe em cena as acusações mais recentes, como se verifica em 24c. Mas a menção não perde de vista que ora se trata das antigas. Fio entre elas, a confusão que se tem da atividade socrática, pois, se se pergunta a quem o acusa o que Sócrates faz e ensina para corromper, os acusadores nada têm a dizer. Mas, novamente para escapar da ignorância e não mostrar embaraço, lançam mão, na seqüência do equívoco, do preconceito que, confundindo planos, equivocadamente nomeia. $\mathrm{O}$ interlocutor de Críton no Eutidemo não deixa, segundo Sócrates, de se comportar de modo semelhante.

Sendo assim, visto que firmado o saber do não saber de Sócrates e o que se formula como sua atividade investigativa, Platão apresenta o nome da atividade 
socrática pela primeira vez, ainda sem, na esteira de Pródico, o definir. Mas, como

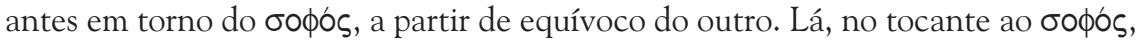
pela inclusão de Sócrates em espécie da qual ele não faz parte. Aqui, ao contrário, pela inclusão, conforme o desenrolar da narrativa, dos que dele se separam, pois para escapar do embaraço incluem a todos na espécie da qual apenas Sócrates faz parte (Ap.23d). O que está a mão - o que está no céu e sob a terra, não reconhecer deuses, e fazer do mais fraco o argumento mais forte - lança-se como acusação para encobrir o que seria o avesso do resultado da refutação socrática: a verdade que eles não quereriam dizer, mas que Sócrates teria mostrado, pois eles, nada sabendo, fingem saber. Prova, Platão modela, é a confusão de planos: sábios, em que se incluem sofistas e fisiólogos, confundem-se na grande barafunda de pretensos sabedores. Para o mistifório geral em que o não saber se arvora como saber, segundo Platão quem filosofa é equivocadamente incluído ou a ele se atribuí o que dele se afasta. No Eutidemo, contudo, os planos diferenciadores são menos nítidos.

No avesso do que Platão estabelece como verdade, há, pois, esta fala ignorante, múltipla e obstinada. Contraponto à filosofia - ainda que esta, não ainda definida, apenas deixe isso se entrever - a ausência requerente aqui busca honrarias $\left(\phi \imath \lambda \iota^{\tau} \imath \mu \mathrm{o}\right)$. O contraponto parte, pois, por modos diversos de vida. A verdade na Apologia não se desvincula deste ponto. Os acusadores, que não a dizem, por esta escolha falam em outra chave: se a voz da verdade ecoa solitária a partir da atividade de Sócrates e, como conseqüência, de sua fala, as vozes que evitam a verdade ressoam ao falar dele em concerto e, por isso, persuasivamente. Assim o contraponto também dissocia numericamente. A persuasão se faz pela multiplicidade e veemência de vozes. Platão formula a diferença de modo a que o $\phi i \lambda \tau \imath \mu$ ऽ precise do outro para ser reconhecido, condenando tudo o que não conhece. A voz dissonante assim se perderia em meio às vozes que há muito e duramente acusando enchem os ouvidos. A persuasão se faz assim por uma constância às avessas. Recusando conhecer-se, reconhecem-se pela fala que, antípoda à verdade, é uníssona na condenação do que desconhece, pois insere Sócrates em diferente espécie; acrescem à sua membros que dela não fazem parte. A Apologia apresenta, pois, o filosofar como ramo antagônico ao desejo de honras e de dinheiro. A atividade de Sócrates, diversamente do Eutidemo, não o confunde com ninguém; com efeito, neste diálogo Sócrates apresenta acusação semelhante àquela que na Apologia contra ele se faz, pois acusa-se Eutidemo e seus seguidores pelo fato de alguém ter revelado ignorância ao ser interrogado.

A verdade é assim forjada como conseqüência da atuação de Sócrates, pois, na contramão da honraria que requereriam os $\phi \mathbf{\imath} \lambda o^{\tau} \tau \mu o \imath$, ela desvelaria meras e 
infundadas pretensões. Ainda sem se nomear como $\phi \imath \lambda \hat{\lambda} \sigma \sigma o \phi o s$, Sócrates contrapõe atividades que visam à diferenciação. Em vez de um saber à venda, ensinável, a distância é apontada por um saber do não saber que refuta supostos saberes. É esta atividade, e sua inabalável continuidade na modelagem de um $\lceil\theta$ os, o que se destaca. Causa da acusação, seu principal fator é o referir a verdade.

A atividade de Sócrates descrita na Apologia não deixa, contudo, de se lançar também enigmaticamente para o leitor. Protréptica, ela transforma missão divina em investigação passível para qualquer homem, pois a mensagem divina se formula como medida humana (Ap.24a-b). Neste sentido, a fala de Sócrates, além de separar a especificidade de sua atividade das demais, aponta a via investigativa de Sócrates como modelar.

Há aqui, contudo, problemas; com efeito, ao afirmar que nada ensina, Platão diz algo diferente daquilo que, ao menos em duas ocasiões, são afirmadas na Apologia como ensino. Sendo assim, a fala no tribunal dirigida ao júri é afirmada por Sócrates como ensinar ( 21 b e $35 b-c)$. Como, então, conciliar estas afirmações de Sócrates? Antes de mais nada, é preciso descartar que Sócrates esteja apenas deixando de lado um ensino como o das $\tau \varepsilon \chi \chi v \alpha$, ou seja, não se trata de afirmar apenas a distinção de um ensino relativo à sabedoria humana, propriamente socrático, de um ensinamento técnico. A resposta está no uso do ع̌ $\lambda \varepsilon \gamma \chi 0 \varsigma$. Neste, diria Sócrates, não há propriamente ensino, pois quem se submete a seu exame não recebe de Sócrates nenhuma informação. Ao contrário, são as próprias crenças do examinado postas em questão. Aqui, contudo, de imediato surgiria a questão: no Eutidemo ò ć $\lambda \varepsilon \gamma \chi$ os não é ensinado?

Permanecem aqui, no entanto, dois problemas relacionados à recusa socrática em ensinar. O ponto é aqui central, pois gravita A Apologia justamente na distinção de Sócrates dos ditos бoфót. Nestes, com efeito, seja em livros, como Anaxágoras, seja por pagamento, como os sofistas, há em ambos, segundo Platão, um ensinamento. A recusa, portanto, do ensinar é fundamental para Sócrates se distinguir deles. É propriamente a marca da atividade que lhe é própria, campo de atuação do que se afirma como sua missão divina. A recusa do ensino é, pois, imprescindível para a demarcação efetuada por Platão entre Sócrates e os denominados бoфór. É preciso assim verificar em que medida estes dois possíveis problemas interferem, visto o perigo da mescla, na diferenciação que Platão estabelece entre a atividade socrática e as denominadas $\sigma o \phi i \alpha$ í, sobretudo a sofística, dado mais próxima de um saber humano.

O primeiro problema é saber em que medida Sócrates ensina ao praticar o

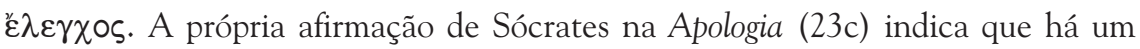


procedimento semelhante da parte dos jovens que o ouvem. Resulta assim que há um resultado efetivo da prática do $\check{c}^{\prime} \lambda \varepsilon \gamma \chi$ os para o qual Platão aqui não mede as conseqüências. Nesta perspectiva ele pode ser praticado como técnica capaz de tornar mais forte o argumento mais fraco. Neste sentido, aproxima-se, sem se dis-

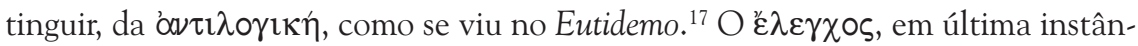
cia, sem o recurso à divindade, opera para a audiência como ensinamento. Apenas

17 Por isso Kerferd (Kerferd, 1999, 55-57) incluir Sócrates entre os sofistas. Para tanto, o que merece ressalvas, ele distingue erística, antilogia e dialética em Platão. Para ele a erística, visando unicamente à vitória, não é propriamente uma técnica de argumento. Falácias, ambigüidades verbais e monólogos podem ser associados com uma ou outra técnica para silenciar o adversário. O Eutidemo é um exemplo deste emprego, em Platão sempre condenado (Kerferd, 1999, p. 62-63). A antilogia, por sua vez, é distinta da erística para Kerferd em Platão pelo sentido dela e pela posição de Platão em relação a ela. Nela "the essential feature is the opposition of one logos to another either by contrariety or contradiction. It follows that, unlike eristic, when used in argument it constitutes a specific and fairly definite technique, namely that of proceeding from a given logos, say the position adopted by a opponent, to the establishment of a contrary or contradictory logos in such a way that the opponent must either accept both logoi, or at least abandon his first position."( Kerferd, 1999, p.63). Para Platão ela não é um método estritamente filosófico, pois permanece em meras contradições verbais, sem apreender, como faz a dialética, a Divisão das coisas pelos Gêneros. Mesmo assim, contudo, para Kerferd ela não implica desonestidade (Rep. 454a). Há a possibilidade, no entanto, de sua má utilização. Citando novamente A República (537a-539b), Kerferd afirma que para Platão ela de fato pode se tornar um instrumento perigoso. Mas ela não deixa de ser parte do processo da dialética (Féd. 85c-d, Rep. 534b). Sendo assim, afirma Kerferd, apenas a dialética pode alcançar a verdade. Desta maneira, Kerferd distingue erística, antilogia e dialética em Platão: "Plato is wholly opposed to eristic, and is completely committed to dialectic. Antilogic for him comes in between eristic and dialectic. It can be used simply for eristic purposes. On the other hand if it is claimed as a sufficient path to truth it also meets with Plato's condemnation. But in itself it is for Plato simply a technique, neither good nor bad. In the early dialogues especially, behind dialectic and leading up to it, there is the prominent technique of argument known as the elenchus, which constitutes perhaps the most striking aspect of behaviour of Socrates. It consists typically of eliciting an answer to a question, such as what is Courage, and then securing assent to further statements which are visibly inconsistent with the answer given to the first question. On rare occasions this leads to something approaching an acceptable modification of the first answer. But far more often the Dialogue closes with the participants in a state of Aporia, unable to see any way forwards or any scape from the contradictory views in which they are enmeshed. This is clearly an application of antilogic." (Kerferd, 1999, p. 65-66). Sendo assim, pode-se afirmar, mais claramente do que faz Kerferd, que não há aqui propriamente um passo para a dialética, o que só ocorrerá posteriormente em Platão, quando um outro Sócrates, com outras preocupações, 
a reversão discursiva de Platão, estribando-se na atividade e no não recebimento de emolumentos, remodela seu ह̌prov.

Por isso resta justificar o porquê de alguns se comprazerem ( $\mu \varepsilon \tau^{\prime}$ ' $\varepsilon \mu o \hat{v} \chi \alpha$ ' povøl) em passar o tempo com Sócrates, pelo que se afirma sua atividade não se

entra em cena. Este primeiro Sócrates de Platão, portanto, ainda mais firmemente na Apologia, visto ser esta um discurso, “(...) it fits in also very well with the picture of others among the sophists who also were concerned with the search for the stronger logos or the correct logos in relation to the conflicting claims of apparently opposite logoi." (Kerferd, 1999, p.57). A divisão de Kerferd implica, pois, problemas. A própria diferença entre erística, antilogia e dialética não funciona nos termos por ele propostos. Nehamas (Nehamas, 1999) os aponta argutamente. Em primeiro lugar, em relação à erística, não se pode se afirmar o uso da falácia como conscientemente empregado. Além do mais, o próprio Sócrates não deixa de usá-la, o que é notado por Protágoras no diálogo (Prot. 350c). Além disso, afirmá-la como vitória apenas aparente implica assumir a diferença entre o que é real e o que é aparente, o que já envolve uma idéia filosófica

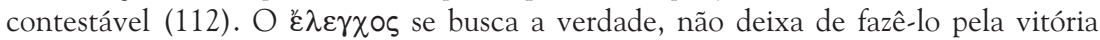
argumentativa (Rep.534c). O máximo que se pode dizer para Nehamas da erística é, em consonância com Kerferd, que ela em Platão não é um método de argumento, mas maus usos da dialética. Quanto à antilogia, no entanto, Nehamas se opõe totalmente à afirmação dela como uma técnica definida. Se há relação entre a antilogia e a contradição, ela não é um método específico, mas o habitualmente empregado por Sócrates. O $\varepsilon \mathcal{\varepsilon} \lambda \varepsilon \chi \chi \circ \varsigma$ assim em nada se distingue da definição de antilogia dada por Kerferd. "Antilogic seems to be not a method distinct from dialectic, but rather the use of dialectic for the purposes of generating (or avoiding) a contradiction" (Nehamas, 1999, p. 114). Citando a mesma passagem da República (539b), Nehamas, ao contrário de Kerferd, afirma que o mau uso é dos próprios argumentos com o propósito de estabelecer antilogias. Não há, pois, dois diferentes métodos de argumento, mas propósitos distintos a que os argumentos podem servir. $\mathrm{O}$ próprio Kerferd concede isso ao afirmar a antilogia como parte da dialética. Assim, afirma Nehamas, "the contrast is purely one of purpose, not of method. One and same method of argument can be used or misused according." (Nehamas, 1999, p.115). Quanto à dialética, Nehamas concorda com Kerferd de que sua compreensão envolve uma aproximação da Teoria das Formas. Com isso, contudo, e nesse sentido se vê o problema da abordagem de Kerferd, o Sócrates dos primeiros diálogos se confunde com o sofista, pois o teste do $\varepsilon \lambda \varepsilon \gamma \chi \chi \circ \varsigma$ visa à vitória pela refutação, pois a verdade só se pode afirmar enquanto não se apresentar um argumento contrário a ela. A única diferença afirmada por Nehamas, a partir do Górgias (458a), é de que Sócrates busca a vitória para o argumento, não para si mesmo. Além disso, Sócrates afirma não possuir um saber que ele pudesse ensinar. Por isso, como bem salienta Nehamas, "the difference between Socrates and the people with whom he was often and not so unreasonably confused is ultimately a difference in purpose, in the sort of life he chose to follow" (Nehamas, 1999, p.117). O mesmo já não distingue Platão, pois este acredita ensinar. Para tanto, a dialética é intimamente relacionada à teoria das Formas. Estas são 
confundir com ensino. Platão ambiguamente a explicita como prazer alheio de ver

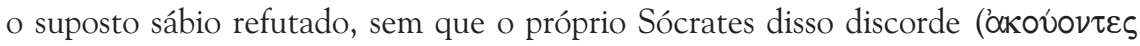

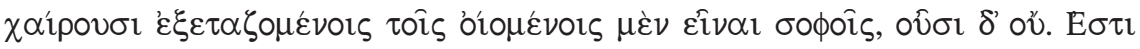

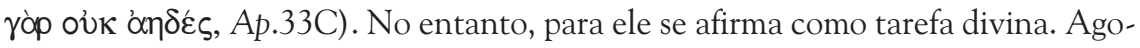
ra hiperbolicamente, visto que, ainda que próximo, justifique-se diversamente sua atividade (Ap.33c). Não fosse a seriedade da ocasião poder-se-ia dizer que a reversão do argumento da acusação, segundo a qual Sócrates é ímpio, prazerosamente é refutada. No limite, tecnicamente é assim descartado o efeito do ensino socrático. Mais do que isso, diversamente do Eutidemo, aqui os que se comprazem não mani-

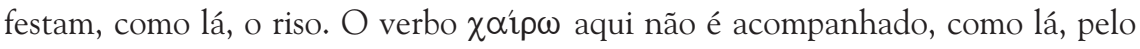
$\gamma \varepsilon \lambda \alpha ́ \omega$ Tais jovens, é de se supor, não deveriam, como os do Eutidemo, deixar de sonoramente demonstrar tal contentamento. No entanto, Platão sobre isso silencia. O filosofar mantém-se sério. Mas o riso dos jovens que o acompanhavam não deixa de ecoar. Justificado pelo oráculo, contudo, Platão faz Sócrates aqui enigmaticamente apenas lançar sinais de sua manifestação.

\section{REFERÊNCIAS Bibliográficas}

EIRE, A. L. "À propos des mots pour exprimer l`idée de "rire” en grec ancien”. In: DESCLOS, M. L. et alli (ed.). Le rire des Grecs. Anthropologie du rire en Grèce ancienne. Editions Jérôme Millon, 2000. p. 13-43.

a natureza real das coisas, distintas das aparências. Com isso, o sofista pode parecer semelhante ao filósofo, mas, conhecida a natureza inalterável, com ele não se confunde. Sendo assim, o próprio Sócrates e o $\varepsilon \lambda \varepsilon \gamma \chi 0 \varsigma$ confundem-se posteriormente em Platão com o sofista (Sof. 230d). Para Nehamas, portanto, apenas com uma controversa teoria, como a das Formas, Platão pode separar o sofista do filósofo. Nesse sentido, ela deve ser feita a partir da própria filosofia. Fora dela, apenas a ausência de ensino, como proposta socrática, pode distingui-lo do sofista, pois ela afirma não ser um professor. No entanto, "nor is it always effective in practice: the effects of the ellenchus, as even Plato himself eventually came to believe may be sometimes difficult to distinguish from the effects of sophistic teaching." (Nehamas, 1999, p.119). Por isso, a meu ver, a necessidade de Platão modelar na Apologia um $\tilde{\eta} \theta$ os para Sócrates que o torne garante do que em última instância se afirma como propósito. Fora isso, sem haver saber, nada há que os distinga, apenas a fluida oposição estrangeiro/cidadão, e a conseqüente diferenciação entre ensinar ou não e para tanto também cobrar ou não. Na Apologia, sobretudo, visto o torno retórico que lhe molda, em momento algum nela se nega o tornar forte $\lambda$ ó ${ }^{\circ} \varsigma$ fraco. 
KERFERD, G.B. The Sophistic Movement. Cambridge: Cambridge University Press, 1999.

MINOIS, G. História do riso e do escárnio. Tradução de M. E. O. Assumpção. EDUNESP, 2003.

NARCY, M. "Le comique, l 'ironie, Socrate". In: DESCLOS, M. L. et alli (ed.). Le rire des Grecs. Anthropologie du rire en Grèce ancienne. Editions Jérôme Millon, 2000. p. 283-292.

NEHAMAS, A. Virtues of Authenticity. New Jersey : Princeton University Press, 1999.

PLATO. Laques, Protagoras, Meno, Euthydemus. Edited and translated by W. R. M. Lamb. London: Harvard University Press, 1977.

PLATO. Euthyphro, Apology, Crito, Phaedo, Phaedrus. Edited and traslated by Harold North Fowler. London: Havard University Press, 1982.

PLATON. Euthydème. Traduction, introduction et notes par M. Canto. Paris: Flammarion, 1989.

ROSSETTI, L. "Le ridicule comme arme entre les mains de Socrate et de ses élèves". In: DESCLOS, M. L. et alli (ed.). Le rire des Grecs. Anthropologie du rire en Grèce ancienne. Editions Jérôme Millon, 2000. p. 253-268.

RIBEIRO, Adriano Machado. Rire et Énigme chez Socrate.

RÉSUMÉ: Cet article cherche montrer comme les différentes façons de joie dans l'Euthydème de Platon s'opposent au sérieux demandépar Socrate par rapport à la philosophie. Ainsi, le rire, le sourire et le rire aux éclats préssuposent un savoir qui humilie un interlocuteur traité comme antagoniste. La tâche de la philosophie, à cause du sérieux de la recherche, doit les laisser de coté. Platon, cependant, jette, dans le dialogue, un certain sourire au lecteur. Dans l'Apologie, outre cela, la tâche socratique semble provoquer un rire semblable à celui-là des jeunes garçons de l'Euthydème. Mais pourquoi Platon énigmatiquement ne le dit pas tout exprès?

MOTS-CLEFS: rire; philosophie; Apologie; Socrate; Platon; Euthydème. 